\title{
Efektifitas Media Video Pembelajaran Matematika Pada Pembelajaran Jarak Jauh (Daring) Di Masa Pandemi Di STKIP Harapan Bima
}

\author{
Muhammad Salahuddin', Muhammad Yamin² \\ ${ }^{1}$ Pendidikan Matematika, STKIP Harapan \\ ${ }^{2}$ Pendidikan Olah Raga, STKIP Harapan Bima \\ Email: muh.ahlan07@gmail.com
}

\begin{abstract}
This research uses a constructive approach with a quasi-experimental type of research. The development method adopts the results of Kuntarto's research, while the development design adopts Creswell's theory. The development method is designed based on OLM criteria. Learning designs are arranged in an interactive form that allows learning activities to be carried out without face-to-face meetings between lecturers and students; can be done at any time; and anywhere as long as an internet connection is available. In order to maintain the validity and reliability of the findings, two tests were carried out, namely normality and homogeneity. The data normality test was carried out using statistics, namely the U-Mann Whitney test with a significance of 5\%. The homogeneity test was carried out with the help of the SPSS program. Collecting data using interviews, questionnaires, and questionnaires. Technical questionnaires and questionnaires were used to express students' impressions and assessments of the types of social media and responses to the online learning model designed. All research instruments used have passed the validity test.
\end{abstract}

Keywords: Video Media, PJJ.

\begin{abstract}
Abstrak
Penelitian ini menggunakan pendekatan konstruktif dengan jenis penelitian kuasi eksperimen. Metode pengembangan mengadopsi hasil penelitian Kuntarto, sedangkan rancangan pengembangan mengadopsi teori Creswell. Metode pengembangan dirancang berdasarkan kriteria OLM. Desain pembelajaran disusun dalam bentuk interaktif yang memungkinkan kegiatan belajar dapat dilaksanakan tanpa tatap-muka antara dosen dan mahasiswa; dapat dilakukan kapan saja; dan di mana saja sepanjang tersedia koneksi internet. Demi menjaga validitas dan reliabilitas temuan maka dilakukan dua uji, yakni normalitas dan homogenitas. Uji normalitas data dilakukan dengan menggunakan statistis, yakni uji $U$ Mann Whitney dengan signifikansi sebesar 5\%. Uji homogenitas dilakukan dengan bantuan program SPSS. Pengumpulan data menggunakan wawancara, angket, dan kuesioner. teknis angket dan kuesioner digunakan untuk mengungkapkan kesan dan penilaian mahasiswa terhadap jenis medsos dan tanggapan terhadap rancangan model pembelajaran daring yang disusun. Semua instrumen penelitian yang digunakan telah melalui uji validitas.
\end{abstract}

Kata Kunci: Media Video, PJJ.

\section{PENDAHULUAN}

Pandemi COVID-19 mempengaruhi hampir semua aspek kehidupan manusia, tak terkecuali pada aspek Pendidikan (Anderson, 2020; Huang et al., 2020). Pada kondisi pandemi peran pada aspek pendidikan sangat krusial (Barennes et al., 2010; Karlsen et al., 2015). Untuk memutus mata rantai penyebaran COVID19 dimana siswa dapat berperan sebagai pembawa dan penyebar penyakit tanpa gejala hampir semua negara meniadakan kegiatan di sekolah dan mengganti pembalajaran di rumah. Pemerintah mengeluarkan edaran melalui surat edaran Kementrian Pendidikan dan Kebudayaan (Kemendikbud) Direktorat Pendidikan Tinggi No 1 tahun 2020 tentang pencegahan penyebaran Corona Virus Disease (Covid-19) di perguruan tinggi. Melalui surat edaran teresebut pihak
Kemendikbud memberikan instruksi kepada perguruan tinggi untuk menyelenggarakan pembelajaran jarak jauh dan menyarankan mahasiswa untuk belajar dari rumah masingmasing. Untuk itu pembelajaran konvensional yang mengumpulkan banyak mahasiswa dalam satu ruangan perlu ditinjau ulang pelaksanaannya. Pembelajaran harus dilaksanakan dengan skenario yang mampu meminimalisir kontak fisik antara mahasiswa dengan melalui pembelajaran digital atau online yang penggunaan teknologi digital yang berbasis online memungkinkan siswa dan guru berada di tempat yang berbeda selama proses pembelajaran. (Aderholt, 2020; Karp, P., \& McGowan, 2020) Pengelolaan sekolah, siswa, orang tua, dan tentu saja guru harus bermigrasi dari pembelajaran tatap muka ke sistem 
pembelajaran digital atau online, yang lebih dikenal dengan istilah e-learning. Secara serentak, mayoritas lembaga pendidikan memilih opsi pembelajaran daring (Azzi-Huck, K., \& Shmis, 2020; Bartlett, J. D., Griffin, J., \& Thomson, 2020; Horn, 2020)

Perubahan pola belajar dan mengajar tentu tak akan pernah terlepas dari peran guru (Thien et al., 2014; Zacharo et al., 2018), terlebih perubahan ke pola pembelajaran daring. Guru harus siap dengan berbagai kondisi pembelajaran dan kondisi siswa, termasuk perkembangan kehidupan di masyarakat (Abdullah, 2016; Zein, 2016). Sehubungan dengan itu, artikel ini bertujuan untuk mereview tentang bagaimana menjadi guru profesional di masa pandemi, yang difokuskan pada review aspek tuntutan digitalisasi dalam dunia pendidikan, khususnya pada aktivitas pembelajaran. Ulasan akan difokuskan kepada bagaimana pelaksanaan pembelajaran di masa pandemi COVID-19 di berbagai negara dan pembelajaran di Indonesia di masa Pandemi COVID- 19, tantangan yang dihadapi dan sekaligus solusi strategis ke depan.

Pembelajaran online pelaksanaannya membutuhkan dukungan perangkat-perangkat mobile seperti handpone android, tablet dan laptop yang dapat digunakan untuk mengakses informasi dimana saja dan kapan saja (Gikas \& Grant, 2013). Penggunaan teknologi mobile memiliki kontribusi yang besar di dunia saat ini khususnya dunia pendidikan, termasuk di dalamnya adalah pencapaian tujuan pembelajaran jarak jauh yang diinginkan (Korucu \& Alkan, 2011). Berbagai media juga dapat digunakan untuk mendukung dalam pelaksanaan pembelajaran secara jarak jauh. Misalnya pembelajaran secara online melalui kelas-kelas virtual menggunakan layanan Google Classroom, Edmodo, dan Schoology (Enriquez, 2014; Iftakhar, 2016; Sicat, 2015), dan applikasi pesan instan seperti WhatsApp (So, 2016). Pembelajaran secara online bahkan dapat dilakukan melalui media social seperti Facebook dan Instagram (Kumar \& Nanda, 2018). Oleh karena itu, penelitian ini membahas tentang persepsi dosen dan mahasiswa tentang penggunaan media video pembelajaran yang notabene sangat diperlukan dalam situasi pandemi seperti COVID19. Sehingga penelitian ini bertujuan untuk menguji keefektifan penggunaan media video pembelajaran saat belajar dari rumah mulai diberlakukan akibat dari pandemi.

\section{METODE}

Penelitian ini menggunakan pendekatan konstruktif dengan jenis penelitian kuasi eksperimen. Metode pengembangan mengadopsi hasil penelitian Kuntarto (Kuntarto, E. \& Asyhar, 2017), sedangkan rancangan pengembangan mengadopsi teori Creswell (Creswell, 2014). Metode pengembangan dirancang berdasarkan kriteria OLM (Alessi, S. M. \& Trollip, 2001; Kuntarto, E. \& Asyhar, 2017). Desain pembelajaran disusun dalam bentuk interaktif yang memungkinkan kegiatan belajar dapat dilaksanakan tanpa tatap-muka antara dosen dan mahasiswa; dapat dilakukan kapan saja; dan di mana saja sepanjang tersedia koneksi internet. Demi menjaga validitas dan reliabilitas temuan maka dilakukan dua uji, yakni normalitas dan homogenitas. Uji normalitas data dilakukan dengan menggunakan statistis, yakni uji U-Mann Whitney dengan signifikansi sebesar 5\%. Uji homogenitas dilakukan dengan bantuan program SPSS.

Pengumpulan data menggunakan wawancara, angket, dan kuesioner. teknis angket dan kuesioner digunakan untuk mengungkapkan kesan dan penilaian mahasiswa terhadap jenis medsos dan tanggapan terhadap rancangan model pembelajaran daring yang disusun. Semua instrumen penelitian yang digunakan telah melalui uji validitas.

\section{HASIL DAN PEMBAHASAN}

Pengembangan dilakukan untuk mendapatkan model pembelajaran daring yang efektif untuk mendukung perkuliahan Matematika di perguruan tinggi. Penerapan model pembelajaran secara daring dilakukan sebanyak empat kali pertemuan, dan diterapkan pada pada 1 kelas pada angkatan 2020 dengan jumlah 4 orang mahasiswa. Seluruh subjek memiliki parangkat ponsel yang tersambung internet dan bisa mengakses e-learning, serta dapat mengoperasikannya dengan baik. 


\section{A. Wawancara}

Dari ke empat subjek yang diwawancarai terdapat jawaban bahwa media video pembelajaran pada pembelajaran jarak jauh mendapat tenggapan positif, selain itu mahasiswa banyak menjawab bahwa media tersebut dapat diakses akapanpun dan dimanapun jika mereka lupa akan materi yang telah lalu. Berikut hasil wawancara dengan salah satu dari ke empat subjek,

P: Menurut Anda pelajaran Matematika cocok menggunakan pembelajaran jarak jauh berupa vidio pembelajaran menggunakan e - learning?

S: Ia cocok

P: Coba jelaskan alasanmu!

$S$ : Alasannya yaitu e-learning bisa diaksek kapanpun dan dimanapun. Berbeda dengan menggunakan zoom dan google meet.

P: Apa bedanya?

S: Jika materi yang di share dipesan zoom atau google meet tidak didownload langsung maka pada saat leave otomatis tidak dapat diakses kembaLi. Berbeda dengan e-learning yang masih bisa di akses jika tidak menggunakan batas waktu

\section{B. Kuesioner}

Materi kuliah diambil dari materi $e$ learning yang lolos hibah PJJ. Penerapan pembelajaran daring dilaksanakan dalam bentuk perkuliahan daring selama 120 menit. Adapun Hasil dari angket pada pertemuan pertama yang telah di isi tampak pada tabel berikut.

\section{Tabel 1. Penilaian Subjek pada angket}

\begin{tabular}{|c|c|c|c|c|c|c|}
\hline & & $\begin{array}{c}\text { PERTEMUAN } \\
1\end{array}$ & $\begin{array}{c}\text { PĚRTEMUAN } \\
2\end{array}$ & $\begin{array}{c}\text { PERTEMUAN } \\
3\end{array}$ & $\begin{array}{c}\text { PERTEMUAN } \\
4\end{array}$ & $\begin{array}{c}\text { TOTAL } \\
\text { TANGGAPAN }\end{array}$ \\
\hline $\begin{array}{l}\text { ASPEK } \\
\text { PENILAIAN }\end{array}$ & penilaian & $\begin{array}{c}\text { Jumlah } \\
\text { tanggapan }\end{array}$ & $\begin{array}{c}\text { Jumlah } \\
\text { tanggapan }\end{array}$ & $\begin{array}{l}\text { Jumlah } \\
\text { tanggapan }\end{array}$ & $\begin{array}{c}\text { Jumlah } \\
\text { tanggapan }\end{array}$ & \\
\hline \multirow{4}{*}{$\begin{array}{l}\text { ASPEK } \\
\text { MATERI }\end{array}$} & Sangat Setuju & 21 & 19 & 13 & 11 & 64 \\
\hline & Setuju & 29 & 28 & 29 & 36 & 122 \\
\hline & Kurang Setuju & 10 & 6 & 11 & 5 & 32 \\
\hline & Tidak Setuju & 2 & 6 & 6 & 7 & 21 \\
\hline \multirow{4}{*}{$\begin{array}{l}\text { ASPEK } \\
\text { MEDIA }\end{array}$} & Sangat Setuju & 4 & 3 & 2 & - & 9 \\
\hline & Setuju & 12 & 14 & 14 & 14 & 54 \\
\hline & Kurang Setuju & 6 & 4 & 6 & 14 & 30 \\
\hline & Tidak Setuju & 5 & 3 & 2 & - & 10 \\
\hline
\end{tabular}

\section{Hasil analisis menggunakan SPSS}

Pada awal pembelajaran, subjek diberikan pre-tes. Pada pertemuan ke-4, subjek diberikan post-tes. Kedua tes tersebut diberikan untuk menguji pemahaman mereka terhadap materi perkuliahan. Baik pre-tes maupun pos-tes, keduanya terdiri atas 10 soal analitik pilihan ganda, dengan empat alternatif pilihan. Hasil tes dapat dilihat pada gambar berikut.

\section{Tabel 2. Hasil Uji Statistik} Test Statistics

\begin{tabular}{lr} 
& \multicolumn{1}{c}{ Hasil Belajar } \\
\hline Mann-Whitney U & .000 \\
\hline Wilcoxon W & 10.000 \\
\hline Z & -2.309 \\
\hline Asymp. Sig. (2-tailed) & .021 \\
\hline Exact Sig. [2*(1-tailed & $.029^{\mathrm{b}}$ \\
Sig.)] & \\
\hline
\end{tabular}

a. Grouping Variable: Kelas

b. Not corrected for ties.

Berdasarkan hasil tes, yang tidak menggunakan media vidio pembelajaran dengan yang menggunakan media vidio pembelajaran Ada perbedaan hasil belajar antara yang tidak menggunakan media video pembelajaran dengan yang menggunakan media video pembelajaran. Sesuai hasil uji U-Mann Whitney dengan output "Test Statistics" diketahui bahwa nilai Asymp. Sig. (2-tailed) sebesar 0,021<0,05. Maka dapat disimpulkan bahwa "Hipotesis Diterima". Dengan demikian dapat dikatakan bahwa ada perbedaan yang signifikan terhadap hasil belajar karena ada pengaruh penggunaan media video pembelajaran pada mata pelajaran matematika. Hal ini mengindikasikan bahwa hasil uji keefektifan penggunaan media video pembelajaran terhadap hasil belajar mata pelajaran matematika mahasiswa program S-1 ada perbedaan yang signifikan terhadap hasil belajar subjek menggunakan pembelajaran konvesional dengan pembelajaran media video pembelajaran PJJ menggunakan e-learning. jumlah rata - rata pada pembelajaran konvesional adalah 10 sedangkan dengan jumlah rata - rata pembelajaran penggunaan media video pembelajaran PJJ adalah 26. Ini menunjukkan adanya perbedaan antara kedua jumlah rerata nilai tersebut mencapai $16 \%$.

\section{KESIMPULAN}

Pembelajaran penggunaan media video pembelajaran PJJ efektif digunakan dalam perkuliahan matematika di program S-1. Model pembelajaran daring telah mampu meningkatkan 
penyerapan mahasiswa terhadap materi kuliah, dengan peningkatan yang mencapai $16 \%$ dibandingkan dengan hanya menggunakan model pembelajaran konvesional. Berdasarkan hasil kuesioner, siswa berpendapat bahwa Pembelajaran penggunaan media video pembelajaran PJJ telah memberikan pengalaman baru yang lebih menantang daripada model pembelajaran konvensional (tatap-muka). Tak terbatas waktu dan tempat belajar memberikan siswa kebebasan untuk memilih saat yang tepat dalam pembelajaran berdasarkan kepentingan mereka, sehingga kemampuan untuk menyerap bahan pembelajaran menjadi lebih tinggi daripada belajar di dalam kelas.

\section{SARAN}

Berdasarkan hasil penelitian ini, disarankan agar dosen matematika menggunakan Pembelajaran penggunaan media video pembelajaran PJJ sehingga suasana pembelajaran siswa lebih aktif, inovatif, kreatif, efektif, dan tidak membosankan, yang pada gilirannya akan meningkatkan motivasi siswa lebih baik prestasi dalam belajar. Berbagai media sosial dapat digunakan untuk mendukung model tersebut.

\section{UCAPAN TERIMA KASIH}

Kami mengucapkan banyak terima kasih terutama kepada pemberi dana penelitian atau donatur yaitu Kemeristek. Ucapan terima kasih dapat juga kami sampaikan kepada pihak-pihak yang membantu pelaksanaan penelitian terutama STKIP Harapan Bima beserta teman - teman dosen.

\section{DAFTAR PUSTAKA}

Abdullah, R. (2016). Pembelajaran dalam perspektif kreativitas guru dalam pemanfaatan media pembelajaran. Lantanida Journal, 4(1), 35-49. https://doi.org/https://doi.org/10.22373/ lj.v4i1.1866

Aderholt, R. (2020). Coronavirus outbreak shining an even brighter light on internet disparities in rural America. The Hill.

Alessi, S. M. \& Trollip, S. . (2001). Multimedia for Learning: Methods and Development. (3rd Ed). Boston MA:
Allyn and Bacon, Inc.

Anderson, J. (2020). Should schools close when coronavirus cases are still rare. Quartz.

Azzi-Huck, K., \& Shmis, T. (2020). Managing the impact of COVID-19 on education systems around the world: How countries are preparing, coping, and planning for recovery. World Bank Blogs.

Barennes, H., Harimanana, A. N., Lorvongseng, S., Ongkhammy, S., \& Chu, C. (2010). Paradoxical risk perception and behaviours related to $\{$ Avian $\}$ Flu $\}$ outbreak and education campaign. Laos. BMC Infectious Diseases. https://doi.org/https://doi.org/10.1186/1 471-2334-10-294

Bartlett, J. D., Griffin, J., \& Thomson, D. (2020). Resources for supporting children's emotional wellbeing during the COVID-19 pandemic. Child Trend.

Creswell, J. W. (2014). Research Design: Qualitative, Quantitative, and Mixed Methods Approaches. Second Edition. LA, London: Sage Publications Inc.

Enriquez, M. A. S. (2014). Students \{Perceptions $\}$ on the $\{$ Effectiveness $\}$ of the $\{$ Use $\}$ of $\{$ Edmodo $\}$ as a \{Supplementary $\} \quad\{$ Tool $\} \quad$ for \{Learning\}. DLSU Research Congress. https://doi.org/https://doi.org/10.1017/ CBO9781107415324.004

Gikas, J., \& Grant, M. M. (2013). Mobile computing devices in higher education: $\{$ Student $\}$ perspectives on learning with cellphones, smartphones I\& social media. Internet and Higher Education. https://doi.org/https://doi.org/10.1016/jj heduc.2013.06.002

Horn, M. B. (2020). COVID-19's long-term impacts on education in 2020 and beyond. EdSurge.

Huang, R. H., Liu, D. J., Tlili, A., Yang, J. F., \& Wang, H. H. (2020). Handbook on facilitating flexible learning during educational disruption: \{The\} \{Chinese experience in maintaining undisrupted learning in \{COVID $\}-19$ \{Outbreak\}. In Smart Learning Institute of Beijing Normal University UNESCO. 
Iftakhar, S. (2016). \{GOOGLE\} \{CLASSROOM $\}$ : $\{$ WHAT $\}$

\{WORKS $\}$ AND $\}$ HOW $\}$ ? Journal of Education and Social Sciences.

Karlsen, H., Mehli, L., Wahl, E., \& Staberg, R. L. (2015). Teaching outbreak investigation to undergraduate food technologists. British Food Journal, $117(2)$, $766-778$ https://doi.org/https://doi.org/10.1108/ BFJ-02-2014-0062

Karp, P., \& McGowan, M. (2020). "Clear as mud" schools ask for online learning help as coronavirus policy confusion persists Australia news. The Guardian.

Korucu, A. T., \& Alkan, A. (2011). Differences between m-learning (mobile learning) and elearning, basic terminology and usage of m-learning in education. Procedia - Social and Behavioral Sciences.

https://doi.org/https://doi.org/10.1016/j. sbspro.2011.04.029

Kumar, V., \& Nanda, P. (2018). Social \{Media $\}$ in \{Higher\} \{Education\}. Nternational Journal of Information and Communication Technology Education. https://doi.org/https://doi.org/10.4018/ij icte.2019010107

Kuntarto, E. \& Asyhar, R. (2017). Pengembangan Model Pembelajaran Blended Learning Pada Aspek Learning Design dengan Platform Media Sosial Online Sebagai Pendukung Perkuliahan Mahasiswa. Repository Unja. Https://Repository.Unja.Ac.Id/Cgi/Use $r s / \quad$ Home? Screen $=$ EPrint $:$ View \&eprintid $=626$.

Sicat, A. S. (2015). Enhancing \{College\} \{Students\} $\quad$ Proficiency\} in \{Business $\} \quad$ \{Writing $\quad\{$ Via \{Schoology\}. International Journal of Education and Research.

So, S. (2016). Mobile instant messaging support for teaching and learning in higher education. Internet and Higher Education. https://doi.org/https://doi.org/10.1016Z j.iheduc.2016.06.001

Thien, L. M., Abd Razak, N., \& Ramayah, T.
(2014). Validating teacher commitment scale using a \{Malaysian\} sample. SAGE Open, 4(2), 1-9. https://doi.org/https://doi.org/10.1177/2 158244014536744

Zacharo, K., Marios, K., \& Dimitra, P. (2018). Connection of teachers' organizational commitment and transformational leadership. $\{\mathrm{A}\}$ case study from \{Greece\}. International Journal of Learning, Teaching and Educational Research, 17(8), 89-106. https://doi.org/https://doi.org/10.26803/ ijlter.17.8.6

Zein, M. (2016). Peran guru dalam pengembangan pembelajaran. Journal UIN- Alauddin, 5(2), 274-285. https://doi.org/https://doi.org/10.24252/ ip.v5i2.3480 